\title{
CHINY
}

Roman Malek

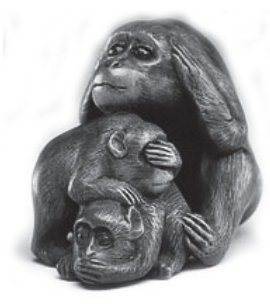

\section{Hexie shehui: NOWA UTOPIA? BUDOWA HARMONIJNEGO I STABILNEGO SPOLECZEŃSTWA CHIŃSKIEGO ORAZ ROLA RELIGII'}

Dzisiejsze Chiny - wbrew monolitycznemu obrazowi, który jeszcze na różnych płaszczyznach pielęgnujemy - są krajem wielonarodowym i wieloreligijnym, w którym wytworzyły się różne warstwy społeczne, kulturalne i religijne. Podziały między poszczególnymi warstwami pogłębiają się coraz bardziej i stają się widoczne w sposób coraz bardziej drastyczny, prowadząc w rezultacie do napięć. Coraz bardziej ujawniają się więc różnice pomiędzy miastem a wsią, między rozwiniętymi prowincjami wybrzeża wschodniego a ubogimi prowincjami na zachodzie kraju. To, co wcześniej było zrozumiałe samo przez się, np. określony poziom wykształcenia lub opieki zdrowotnej, stało się obecnie dostępne tylko dla tych, którzy mają pieniądze. Z tej skomplikowanej sytuacji wyrosło wiele problemów społeczno-politycznych, do których należą: bezrobocie, utrata ziemi uprawnej, zanieczyszczenie środowiska, migracja, niezadowolenie społeczne, korupcja, brak reform politycznych, lekceważenie dokonujących się zmian społecznych i psychicznych itd. Władze chińskie dokładnie zdają sobie sprawę z tego, iż w Chinach jest ponad 150 mln ludzi bogatych i $900 \mathrm{mln}$ biednych - i że to stać się może czynnikiem powodującym destabilizację. Nie dziwi w związku z tym aktualna polityka partii i rządu, która poszukuje wszelkich możliwych środków, zmierzających do zachowania jedności państwa oraz do tzw. harmonii i stabilności w społeczeństwie. Harmonia i stabilizacja mają być przedmiotem starannej pielęgnacji i ochrony ,jak źrenicy oka” - jak to określa komentarz „Renmin Ribao” [Gazety Ludowej]. Stabilność rozumie się przy tym jako fundament harmonijnego społeczeństwa. Bez stabilno-

${ }^{1}$ Przedruk za zgodą autora z czasopisma „Chiny Dzisiaj: Religie - Chrześcijaństwo - Kościół”, numer wstępny 2006. Tekst w jęz. niemieckim ukazał się w „China Heute” 2006, nr 1. 
ści nie można osiagnąć społeczeństwa harmonijnego oraz postępu w zakresie modernizacji - jak przykładowo stwierdza organ partyjny „Qiushi” [Szukać Prawdy] z 1 października $2005 \mathrm{r}$.

Idea harmonijnego i stabilnego społeczeństwa wyłoniła się po raz pierwszy na 4 Plenum XVI Komitetu Centralnego we wrześniu 2004 r. Harmonijnej społecznej stabilizacji kraju była następnie poświęcona specjalna konferencja KC Komunistycznej Partii Chin (KPCh) z 19 lutego 2005 r., podczas której sekretarz generalny Hu Jintao wygłosił przemówienie programowe. Odtąd temat harmonii i stabilności jest „wszechobecny i wiodący” - jak to określają oficjalne chińskie media - „,ciesząc się coraz większym uznaniem w partii i wśród ludności”. Społeczeństwo harmonijne (hexie shehui) - w półoficjalnych angielskich przekładach chińskich dokumentów tłumaczone jako harmonious society albo coordinated society - przedstawiane jest jako społeczeństwo demokratyczne, które rządzi się według prawa (państwowość prawna), co w rezultacie ma prowadzić do sprawiedliwości, uczciwości i szczerości oraz do harmonii z naturą (środowiskiem). Na bazie harmonii i stabilności Chiny mają stać się zamożnym i silnym krajem ze społeczeństwem ,powściagliwego dobrobytu” (xiaokang shehui). Wszystkie te aspekty winny być ze sobą interaktywnie połączone. Taki kraj i takie społeczeństwo mogłoby następnie przyczynić się do harmonii i stabilności na całym świecie. Summa summarum chodzi o budowę doskonałej i idealnej społeczności, o rozwój all-round - jak powiedział Hu Jintao - w budowie cywilizacji socjalistycznej, materialnej, politycznej i duchowej. Nie chodzi więc już tylko o „trojaką budowę”, mianowicie: ekonomiczną, polityczną i kulturalną - jak to było wcześniej, lecz o „czworaką budowę", mianowicie: ekonomiczna, polityczną, kulturalną i społeczną. Te cztery aspekty razem tworzą społeczeństwo harmonijne i stabilne.

Idea harmonijnego i stabilnego społeczeństwa jest właściwie rozwinięciem idei tzw. „,trzech reprezentacji” (sange daibiao) byłego przywódcy partii Jiang Zemina. To prawie tak, jak w starych Chinach, gdzie cesarz każdorazowo, z uwagi na polityczne i społeczne okoliczności, dodawał do swego imienia jakąś odpowiednią „dewizę rządową”. Tak, jak „trzy reprezentacje” obowiązywały jako „,dewiza rządzenia" jeszcze do 2004 r., tak idea harmonijnego i trwałego społeczeństwa jest według Hu Jintao nową „dewizą rządową”. Powodzenie w budowie harmonijnego i trwałego społeczeństwa jest rozumiane równocześnie jako sprawdzian zdolności KPCh do rządzenia krajem.

Do oczekiwanej, a przy tym zawsze zagrożonej, harmonii i stabilności kraju powinna przyczyniać się także polityka wobec religii oraz polityka wobec mniejszości narodowych. „Potrójna jedność etniczna” (wyrażająca się w tym, że - 1 . dominująca narodowość Han nie jest za jej oddzieleniem czy wyróżnianiem od mniejszości etnicznych, które z kolei także - 2. nie są za separacją od narodowo- 
ści Han, jak również - 3. nie są zwolennikami podziałów między sobą) oraz „harmonia religijna", jak to sformułował Hu Jintao, są ważnymi składnikami budowy harmonijnego i stabilnego społeczeństwa. Według wyobrażeń partii, religie powinny dostosować się do dzisiejszych czasów i do nowoczesnego społeczeństwa. Powinny nadto wspierać studia dotyczące religii, ażeby przyczynić się do podniesienia w społeczeństwie poziomu wykształcenia i w ten sposób dać przykład patriotyzmu, czyli „miłości do kraju i religii” (aiguo aijiao).

Budowa harmonijnego i trwałego społeczeństwa winna naturalnie odpowiadać także wszystkim nowym rozporządzeniom i przepisom, jakimi są m.in. obowiązujące od listopada 2004 r. nowe przepisy w zakresie religii. Powinna ona respektować także nowe normy działalności publicystycznej dziennikarzy i redaktorów, obowiązujące od kwietnia 2005 r., jak również wiele innych restrykcyjnych przepisów (np. w odniesieniu do Internetu). W intencji władz chińskich przepisy te mają przeciwdziałać tym siłom w społeczeństwie, które szkodzą jego harmonii i stabilności.

Wkład religii. Religie mają samodzielnie szukać dróg ku temu, aby coraz bardziej przyczyniać się do budowy harmonijnego i stabilnego społeczeństwa. Zwrócił na to uwagę przewodniczący Politycznej Konferencji Konsultacyjnej Jia Qinglin na specjalnym seminarium 1 marca 2005 r. Od tego czasu odbyły się na ten temat niezliczone seminaria oficjalnych organizacji religijnych, jak również innych gremiów. Wzrosła liczba artykułów publikowanych w czasopismach wspólnot religijnych i instytutów naukowych, a także urzędów, które zajmują się religiami (oczywiście wiodący jest tu periodyk Narodowego Biura ds. Religii „Zhongguo Zongjiao" [Religie Chińskie]. Wszystkie oficjalnie uznane wspólnoty religijne wypowiadały się już na ten temat w swoich oficjalnych organach. Argumenty na rzecz harmonii i stabilności starano się w równej mierze podpierać Pismem św., Koranem, pismami buddyjskimi i daoistycznymi, jak i tzw. „konfucjańską” klasyką. Temu celowi służą także coroczne uroczyste obchody urodzin Konfucjusza w Qufu (prowincja Shandong). Organizowane są konferencje poświęcone np. konfucjanizmowi jako „fundamentowi moralnemu”, który mógłby służyć harmonijnemu i stabilnemu społeczeństwu.

Jak ma wyrażać się wkład ludzi wierzących w harmonię religijną i społeczną? W publikacjach oraz wykładach konferencyjnych stwierdza się przede wszystkim, że dyskusja o roli religii w harmonijnym i stabilnym społeczeństwie pokazuje, iż religia jest integralną i trwałą częścią kultury - w tym również kultury chińskiej. W związku z tym budowa „kultury religijnej” (zongjiao wenhua) wymaga, ażeby opierać ją na podstawach etycznych (daode) odnośnych religii. Sformułowanie takie nie jest wprawdzie czymś nowym w chińskich dyskusjach religioznawczych, 
jednakże istotne jest - jeśli tak można powiedzieć - „polityczne” uznanie faktu istnienia religii jako integralnej części kultury chińskiej. Pociąga ono za sobą odpowiednie religijno-polityczne spojrzenie na religię oraz na praktykę polityki religijnej w Chińskiej Republice Ludowej (ChRL). Idea hexie shehui stała się w ten sposób także nowym planem ,pracy religijnej partii” - jak sformułował to Wang Zuo'an, zastępca dyrektora Narodowego Biura ds. Religii, które w tym duchu chce stworzyć nowe założenia i perspektywy państwowej polityki religijnej. Mając na uwadze religie, politycy i teoretycy mówią także o, wewnętrznej harmonii religijnej” (zongjiao neibu hexie), która powinna tworzyć podstawę współistnienia religii z komunistycznym państwem chińskim. Przede wszystkim zaś usiłuje się tworzyć jedność międzyreligijną w myśl tradycyjnej, pochodzącej z chińskiej historii religii, zasady sanjiao heyi, tzn. „trzy religie stanowią jedność”.

Religie w ChRL próbują dziś w różny sposób artykułować swój wkład w budowę harmonijnego społeczeństwa, czyli wykorzystać szansę na większą „,widoczność” społeczną. Można nawet powiedzieć, że dyskusja polityczna o harmonii i stabilności w społeczeństwie sprowokowała refleksję teologiczną w łonie samych religii. Ma to też dobre strony, gdyż poszczególne religie mogą obecnie (oczywiście w ramach państwowego nadzoru) przedstawiać własne, specyficzne stanowisko na tematy społeczne. Dzięki temu uwydatnione zostało też wiele tradycyjnych idei i punktów widzenia. Niektóre elementy tych argumentacji w poszczególnych religiach zostaną poniżej streszczone.

Kościół katolicki. Wkład Kościoła katolickiego do harmonijnego i stabilnego społeczeństwa przedstawia się przede wszystkim na płaszczyźnie chrześcijańskiej miłości bliźniego (jidu de ai). Zarazem akcentuje się, że Kościół sam powinien się starać o „harmonię wewnętrzną” (zishen hexie). Harmonia wewnętrzna i harmonia społeczna (shehui hexie) to hasła, które obecne są w oficjalnych wypowiedziach katolickich.

Wskazano na następujące aspekty, uznane za typowo katolicki wkład w budowę harmonijnego społeczeństwa: 1. Kształtowanie świadomości patriotycznej, co przypomina formułę aiguo aijiao (miłość do kraju i do Kościoła), oraz kontynuowanie tzw. demokratycznej administracji Kościoła; 2. Wykształcenie teologiczne: tu wskazano na konieczność dokonania korekty w zakresie eklezjologii i duchowości. Zwrócono też uwagę, iż należy pracować nad pojednaniem teologii katolickiej z kulturą i filozofią chińską; 3 . W związku z nową sytuacją i nowymi wymaganiami społecznymi należy rozwinąć trzy elementy: (a) nowe statuty Stowarzyszenia Patriotycznego; (b) nowe statuty konferencji biskupów; (c) nowe reguły demokratycznej administracji Kościoła, do czego należy także dalszy rozwój idei „trzech autonomii” (sanzi). Osiaggnięcie harmonii wymaga, jak stwierdzono, 
postępu w zakresie rozwoju doktryny katolickiej; 4. Jako wkład do harmonijnego i stabilnego społeczeństwa została zaliczona także implementacja państwowych przepisów religijnych.

Z etycznego punktu widzenia zwrócono uwagę na następujące elementy: (a) głoszenie i rozpowszechnianie katolickiej nauki moralnej, przede wszystkim w aspekcie stosunku Kościoła do społeczeństwa. Biblijne dziesięć przykazań i przykazania kościelne mogłyby odegrać tu dużą rolę. Katolicy powinni przestrzegać przykazań, aby być dobrymi, wzorowymi obywatelami; (b) szerzenie nauki biblijnej, przede wszystkim chrześcijańskiego przykazania miłości bliźniego. Kościół powinien brać udział w budowie harmonijnego społeczeństwa przede wszystkim w zakresie społecznym i charytatywnym. Wskazano też na dalsze dziedziny, które mogłyby przyczynić się do budowy harmonijnego społeczeństwa, jak np. działania na rzecz sprawiedliwości, pokoju czy ochrony środowiska. Ze strony wiary wskazano na chrześcijańską miłość bliźniego jako na wielki wkład w tworzenie harmonijnego społeczeństwa: Miłość jest harmonią $(a i=h e x i e)$; na miłości bliźniego wznosi się nowe społeczeństwo. Miłość mogłaby więc kształtować międzyludzkie stosunki i uwrażliwiać sumienia. W ten sposób powstałaby „kultura chrześcijańska” (Jidu wenhua), kultura służby bliźniemu, która jest pierwszym zadaniem Kościoła. Innym wkładem byłaby idea Królestwa Bożego (tianguo), które powinno być budowane już na ziemi jako harmonijne społeczeństwo.

Znany dziennikarz Li Haibo zaznaczył w „Beijing Review” (13 maja 2005, s. 2), że harmonia jest ważną ideą chrześcijańską oraz że ideał miłości bliźniego powinien być podstawą stosunków międzyludzkich. W tym sensie uważa on, że „kombinacja kultury chińskiej i chrześcijaństwa” mogłaby przynieść w przyszłości owoce. Także inni intelektualiści zaznaczają, że chrześcijaństwo byłoby w stanie dokonać wielkiego wkładu do harmonijnego i stabilnego społeczeństwa, a zatem także w rozwój „społeczeństwa cywilnego”.

Islam. Gdy idzie o wkład islamu, to wskazuje się w szczególności na rolę stosunków między wiernymi (wyznawcami islamu) i „niewiernymi” przy budowie harmonijnego i trwałego społeczeństwa. Hexie oznacza dla islamu przede wszystkim: 1. obalenie wzajemnych uprzedzeń; 2. nawiązywanie kontaktów na rzecz dialogu międzykulturowego i międzyreligijnego; 3. rozwijanie wzajemnej sympatii i zaufania w duchu Koranu. Harmonijne społeczeństwo opiera się, według islamskich przekonań, na poszczególnych ludziach. Człowiek sam powinien dążyć do harmonii, tak samo jak rodzina. Koran daje w tym względzie ważne wskazówki (mówi na ten temat artykuł „Idea harmonii w Koranie” w oficjalnym czasopiśmie Stowarzyszenia Islamskiego „Zhongguo Musilin” z 2005 r., nr 3). Stosunki międzyludzkie powinny być zatem budowane na harmonii indywidualnej oraz rodzinnej. Wkład 
islamu można następnie określić jako przyczynianie się do sprawiedliwości i pokoju, poszukiwanie prawdy, ochronę natury i środowiska. Muzułmańska moralność wymaga, aby wiara i praktyka życiowa szły w parze. Będzie się więc kładło nacisk na to, aby wśród wyznawców islamu wzrosła znajomość prawa chińskiego oraz norm, zwłaszcza z zakresu polityki religijnej, co jest niezbędne dla tworzenia harmonijnego i trwałego społeczeństwa - głosi oficjalne stanowisko Stowarzyszenia Islamskiego.

Daoizm. Opinie środowisk daoistycznych wskazują na to, że hexie jest ideą na wskroś daoistyczną, gdyż mówi o niej wiele daoistycznych pism, mistrzów i szkół, które dają jednocześnie różnorakie wskazówki, w jaki sposób można harmonię osiagnaćc. Również w daoizmie wskazuje się na konieczność osiagnięcia „harmonii wewnętrznej” i w tym duchu należy budować „kulturę daoistyczną” (daojiao wenhua), która będzie opierać się na daoistycznej etyce i stanie się składnikiem harmonijnego i trwałego społeczeństwa chińskiego.

Buddyzm. Także opinie środowisk buddyjskich wskazują, że harmonia jest celem buddyzmu i że buddyzm oferuje różnorakie metody, ażeby osiagnąć harmonię zewnętrzną i wewnętrzną. Fundamentem społecznej harmonii i pokoju powinna być wszelako harmonia ludzkich serc. Ażeby doprowadzić do harmonijnego i stabilnego społeczeństwa, buddyści powinni pielęgnować kulturę wewnętrzną i działać według ideału równości i miłosierdzia w stosunku do całego stworzenia. Postulowane jest również tworzenie „kultury buddyjskiej” (fojiao wenhua) na podłożu buddyjskiej etyki.

Roli buddyzmu w budowie harmonijnego i stabilnego społeczeństwa poświęcone było sympozjum w Hongkongu, w którym udział wzięli mnisi z ChRL oraz z Hongkongu - m.in. Żywy Budda Saicang Luozang Huadan z klasztoru Derlong, w prowincji Gansu. Uczestnicy kładli nacisk zwłaszcza na buddyjską empatię jako na wielki możliwy wkład buddyzmu do harmonijnego i stabilnego społeczeństwa.

Podsumowanie. Próby stworzenia społeczeństwa harmonijnego nie są w chińskiej historii czymś nowym. Hu Jintao w przemówieniu z lutego 2005 r. powoływał się nie tylko na Konfucjusza (551-479 r. przed Chr.), który bardzo cenił ideę harmonii (he), lecz także nieortodoksyjnego filozofa Mozi (ok. 479-381 przed Chr.), który głosił „wszechogarniającą miłość” (jian ’ai) oraz na Księgę Rytów (Liji), gdzie w rozdziale „Liyun” (Stosowanie rytów) opisane zostało społeczeństwo idealne. Znamienne jest również to, że Hu Jintao wspomniał chińsko-chrześcijańskiego powstańca Hong Xiuquana (1814-1864) i jego ideę Królestwa Bożego Pokoju (Tai- 
ping tianguo). Idea „Wielkiej Harmonii” względnie „Wielkiej Wspólnoty” głoszona był także przez sławnego myśliciela Kang Youwei’a (1858-1927) w jego dziele Datong shu (Księga Wielkiej Harmonii). Hu Jintao w swojej genealogii harmonijnego i stabilnego społeczeństwa powołał się naturalnie również na klasyków marksizmu i leninizmu z Zachodu. Wspomniał oczywiście także Mao Zedonga i Deng Xiaopinga. Można jeszcze dodać, że w latach dwudziestych XX w. wielcy protestantcy chrześcijanie, jak np. Wu Leichuan (1869-1944), Xu Baoqian (1892-1944) i Zhao Zichen (1888-1979) próbowali zaadaptować chrześcijańską ideę Królestwa Niebieskiego względnie Królestwa Bożego w celu reformy społeczeństwa chińskiego i według niej chcieli to społeczeństwo formować.

Aby zilustrować tradycyjną chińską ideę harmonii, należy przypomnieć opis z Księgi rytów (Liji, rozdział „Liyun”), który został zacytowany w przemówieniu Hu Jintao. W rozdziale tym mówi się o tym, że w czasie, kiedy panowała „Wielka Droga" (Dao), świat należał do wszystkich. Do rządów wybierało się tylko dzielnych i zdatnych, mówiło się prawdę i pielęgnowało zgodę. Dlatego ludzie kochali nie tylko swoich własnych rodziców i troszczyli się nie tylko o swoje własne dzieci. Starcy mogli wypatrywać swego końca w spokoju. Silni mężczyźni mieli pracę; wdowcy i wdowy, sieroty, bezdzietni i chorzy - wszyscy mieli opiekę. Mężczyźni mieli swoje stanowiska, a kobiety swój dom. Nie szukano dóbr materialnych tylko po to, aby je gromadzić. Nie marnowano własnych sił, a pracowano nie tylko ze względu na własną korzyść.

Widać więc wyraźnie, że idea harmonijnego i trwałego społeczeństwa propagowana jest obecnie jako namiastka komunizmu, jako pomysł na nowe utopijne społeczeństwo, które znajduje się ponadto w procesie globalizacji. Tak twierdzi np. filozof Tang Yijie, który w przeciwieństwie do idei „walki kultur” Samuela P. Huntingtona wskazał na harmonijne współistnienie cywilizacji, do którego Chiny mogą wnieść wkład poprzez harmonijne i stabilne społeczeństwo. W tym samym duchu niektóry teoretycy, jak np. Zheng Bijian, przewodniczący Chińskiego Forum Reform, przepowiadają wielką transformację i „odrodzenie cywilizacji chińskiej" na całym świecie. 15 września 2005 r. Hu Jintao na forum ONZ referował ideę „harmonijnego świata" poprzez dialog i wymianę oraz sformułował roszczenia Chin w tym procesie.

Harmonijne i stabilne społeczeństwo jest - jak zauważył Thomas Heberer - powrotem do „konfucjańskiego modelu” albo ideału „Wielkiej Harmonii” (datong). Los takiej wspólnoty jest jednak niepewny. W chińskiej historii tego typu próby były częste i aż do czasów najnowszych kończyły się fiaskiem - jak to pokazał Wolfgang Bauer w swojej znanej książce Chiny i nadzieja na szczęście. Pozostaje więc mieć nadzieję, że nie wszystkie aktualnie podjęte starania o harmonię okażą się daremne, ale że przynajmniej niektóre próby będą prowadzić do rozwoju spo- 
łeczeństwa cywilnego przy zachowaniu prawdziwej demokracji, respektowaniu praw człowieka i wolności religijnej. Pomimo wszelkich przytoczonych tu sformułowań i wyjaśnień o harmonii, te ostatnie elementy (demokracja, wolność, prawa człowieka) są nadal nieobecne w oficjalnych wypowiedziach na temat harmonijnego i stabilnego społeczeństwa. Restrykcyjna polityka przeciwko wszystkim „czynnikom dysharmonii i destabilizacji” trwa więc nadal.

\section{Literatura:}

Wolfgang Bauer, China und die Hoffnung und Glück. Paradiese, Utopien, Idealvorstellungen in der Geistesgeschichte Chinas, München 1971; Th. Heberer, Soziale Sicherung und Soziale Hilfe: Schritte zur Harmonisierung der Gesellschaft im gegenwärtigen China, „China Heute” 2005, s. 152-160; Richard Wilhelm, Li Gi. Das Buch der Sitte, Jena 1930, s. 30n.; „Zhongguo Daojiao” 2005, nr 4; „Zhongguo Musilin” 2005, nr 4; „Zhongguo Tianzhujiao” 2005, nr 3-5; „Zhongguo Zongjiao” 2005, nr 8-9; www.chinaview.cn

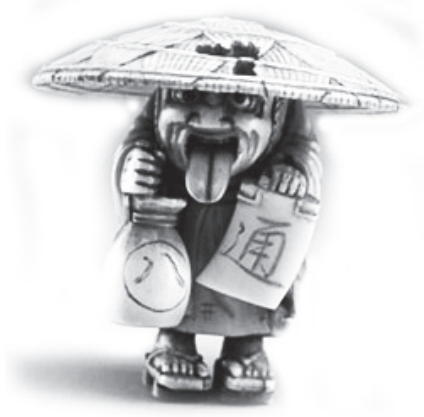

